\title{
Viscosity and density models for copper electrorefining electrolytes
}

\author{
Taina Kalliomäki ${ }^{1, a}$, Arif T. Aji ${ }^{1}$, Jari Aromaa ${ }^{1}$, and Mari Lundström ${ }^{1}$ \\ ${ }^{1}$ Department of Materials Science and Engineering Aalto University, Vuorimiehentie 2, 02150 Espoo, Finland
}

\begin{abstract}
Viscosity and density are highly important physicochemical properties of copper electrolyte since they affect the purity of cathode copper and energy consumption $[1,2]$ affecting the mass and heat transfer conditions in the cell [3]. Increasing viscosity and density decreases the rate in which the anode slime falls to the bottom of the cell $[4,5]$ and lowers the diffusion coefficient of cupric ion $\left(D_{\mathrm{Cu} 2}\right)$ [6]. Decreasing the falling rate of anode slime increases movement of the slime to other directions than downward $[4,5]$. If the anode slime ends up on the cathode, the impurities could entrap into coating [4]. Due to that the aim is to keep the viscosity and density sufficiently low [4]. According to the studies of Price and Davenport [3], Subbaiah and Das [2], Devochkin et al. [7] as well as Jarjoura et al. [8] increasing the concentration of copper, nickel and sulfuric acid increases both viscosity and density, while temperature decreases these properties. In addition, Price and Davenport [1] researched the effect of impurities arsenic and iron as well as Subbaiah and Das [2] the effect of iron, manganese and cobalt. All of these researchers found that those impurities increased both viscosity and density. The density and kinematic viscosity of copper electrorefining electrolytes have not been extensively researched under electrorefining conditions. The kinematic viscosity is also an important factor in the equation defining $D_{\mathrm{Cu} 2+}$ using a rotating disc electrode technique [6]. The errors in the viscosity values cause significant error to $D_{\mathrm{Cu} 2+}$. Thus, this work introduces mathematical models for the density and kinematic viscosity. The kinematic viscosity of the test electrolytes was measured with a Ubbelohde capillary viscometer from Schott-Geräte $\mathrm{GmbH}$ and the density with a glass tube oscillator DMA 40 Digital Density Meter from Anton Paar K. G. The temperature $\left(50,60,70{ }^{\circ} \mathrm{C}\right)$ and electrolyte composition were used as variables. The composition variables investigated were copper (40, $\left.50,60 \mathrm{~g} / \mathrm{dm}^{3}\right)$, nickel $\left(0,10,20 \mathrm{~g} / \mathrm{dm}^{3}\right)$ and sulfuric acid $\left(130,145,160 \mathrm{~g} / \mathrm{dm}^{3}\right)$ in all models, and additionally the effect of arsenic acid for the viscosity was studied $\left(0,15,30 \mathrm{~g} / \mathrm{dm}^{3}\right)$. The electrolytes used in these tests were prepared from $\mathrm{CuSO}_{4} \cdot 5 \mathrm{H}_{2} \mathrm{O}(99-100 \%), \mathrm{NiSO}_{4} \cdot 7 \mathrm{H}_{2} \mathrm{O}$ (99-100\%), $\mathrm{H}_{2} \mathrm{SO}_{4}(95-97 \%)$ and arsenic acid (containing As $151700 \mathrm{mg} / \mathrm{dm}^{3}$, Bi 6.2 $\mathrm{mg} / \mathrm{dm}^{3}$, Se $0.07 \mathrm{mg} / \mathrm{dm}^{3}$, Te $18.6 \mathrm{mg} / \mathrm{dm}^{3}$, Ag $0.2 \mathrm{mg} / \mathrm{dm}^{3}$, Cu $4794 \mathrm{mg} / \mathrm{dm}^{3}$, Ni 1688 $\mathrm{mg} / \mathrm{dm}^{3}, \mathrm{~Pb} 28.62 \mathrm{mg} / \mathrm{dm}^{3}$ and $\mathrm{Sb} 3954 \mathrm{mg} / \mathrm{dm}^{3}$ ). The results were normalized using known water values for viscosity as well as water and air values for the density. Based on these results the models for density $\left(\rho, \mathrm{g} / \mathrm{cm}^{3}\right)$ and kinematic viscosity $\left(v, \mathrm{~mm}^{2} / \mathrm{s}\right)$ were designed, refined and analyzed using modeling and design tool MODDE, Equation 1 for density and 2 for kinematic viscosity:
\end{abstract}

${ }^{a}$ Corresponding author: taina.kalliomaki@aalto.fi 


$$
\begin{aligned}
& \rho=1.03473+0.00216707[\mathrm{Cu}]+0.000535362\left[\mathrm{H}_{2} \mathrm{SO}_{4}\right]+ \\
& 0.00234682[\mathrm{Ni}]-0.000713461 T
\end{aligned}
$$

$$
\begin{aligned}
& v=0.07989+0.002868[\mathrm{Cu}]+0.0005293\left[\mathrm{H}_{2} \mathrm{SO}_{4}\right]+0.003349[\mathrm{Ni}]+ \\
& 0.004768[\mathrm{As}]-0.007038 T-2.175 \cdot 10^{-05} T[\mathrm{As}]
\end{aligned}
$$

The designed model of density (Equation 1) and viscosity (Equation 2) were in a good agreement with the results of Price and Davenport [1] and Devochkin et al [7] when the effect of As was not included (Figs. 1 and 2). However, the density values of Subbaiah and Das [2] were slightly lower than the obtained this work, and it should be noted that the model of Subbaiah and Das [2] was constructed of results mainly measured at $30{ }^{\circ} \mathrm{C}$. That is outside the range of the temperatures used in the electrorefining process. Moreover, the viscosity values defined with the current model were higher than the equivalent values of Price and Davenport [1], when the effect of As was taken into account (Fig. 2).

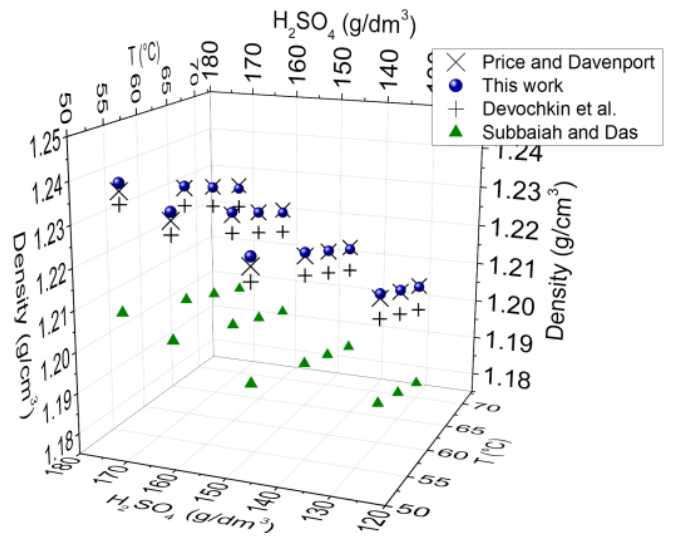

Figure 1. Copper electrorefining electrolyte density as a function of $\mathrm{H}_{2} \mathrm{SO}_{4}$ and temperature, plotted using models from this work, and models of Price and Davenport[1], Subbaiah and Das [2] and Devochkin et al. [7] with $[\mathrm{Cu}(\mathrm{II})]=50 \mathrm{~g} / \mathrm{dm}^{3}$ and $[\mathrm{Ni}(\mathrm{II})]=18 \mathrm{~g} / \mathrm{dm}^{3}$.

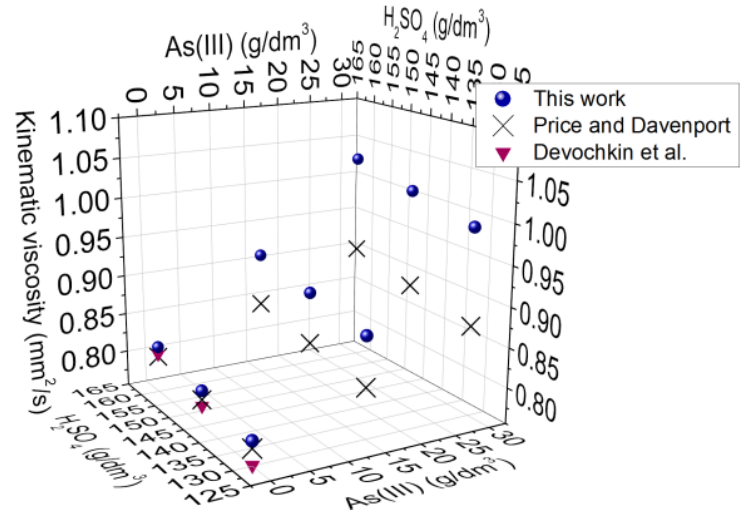

Figure 2. Copper electrorefining electrolyte kinematic viscosity as a function of As(III) and $\mathrm{H}_{2} \mathrm{SO}_{4}$ plotted using models from this work, and models of Price and Davenport [1] and Devochkin et al. [7] and with $[\mathrm{Cu}(\mathrm{II})]=50 \mathrm{~g} / \mathrm{dm}^{3}$ and $[\mathrm{Ni}(\mathrm{II})]=18 \mathrm{~g} / \mathrm{dm}^{3}$. 


\section{References}

1. D.C. Price, W.G. Davenport, Metall. Trans. B, 12(B), 639 (1981)

2. T. Subbaiah, S.C. Das, Metall. Trans. B, 20(B), 375 (1989)

3. D.C. Price, W.G. Davenport, Metall. Trans. B, 11(B), 159 (1980)

4. W.G. Davenport, M. King, M. Schlesinger, A.K. Biswas, T. Robinson, Extractive Metallurgy of Copper, 4th edn.(Elsevier Science Ltd., 2002)

5. Y. Shi, Z. Ye, An, in Proceedings of $4^{\text {th }}$ International Symposium on High Temperature Metallurgical Processing (2013)

6. M.S. Moats, J.B. Hiskey, D.W. Collins, Hydrometallurgy, 56, 255 (2000)

7. A.I. Devochkin, I.S. Kuzmina, E.V. Salimzhanova, L.I. Petukhova, Tsvetnye Metally, 2015(6), $67(2015)$

8. G. Jarjoura, M. Muinonen, G.J. Kipouros, Canadian Metall. Q., 42(3), 281(2003) 